\section{QUALIMETRIC METHOD OF ASSESSING RISKS OF LOW QUALITY PRODUCTS}

ROMAN TRISHCH ${ }^{1}$, OLESIA NECHUIVITER ${ }^{1}$, KOSTIANTYN $^{2}$
DYADYURA ${ }^{2}$, OLEKSANDR VASILEVSKY ${ }^{3}$, IRYNA
TSYKHANOVSKA $^{1}$, MAKSYM YAKOVLEV

${ }^{1}$ Ukrainian Engineering Pedagogics Academy (Kharkiv, Ukraine)

${ }^{2}$ Sumy State University, Faculty of Technical Systems and Energy

Efficient Technologies, Sumy, Ukraine

${ }^{3}$ Vinnytsia National Technical University, Vinnytsia, Ukraine

${ }^{4}$ National academy of the National guard of Ukraine

DOI: 10.17973/MMSJ.2021_10_2021030

e-mail: dyadyura@pmtkm.sumdu.edu.ua

Risk assessment is an integral part of an enterprise's quality management system. The risk of low quality products is the most significant risk, as it is directly related to the concept of enterprise competitiveness. The paper analyzes the scientific papers related to the assessment of the quality of products, processes and services, their disadvantages, possible limits of application. It is proposed to use mathematical dependences to obtain estimates of product quality indicators on a dimensionless scale. Knowing the density function of random variables of product quality indicators and knowing the mathematical dependence of their estimates on a dimensionless scale, it is proposed to obtain the density function of estimates. Knowing the function of the density of estimates of quality indicators, it is proposed to find the probabilities of risks of the assessment of quality indicators in any given interval on a dimensionless scale. A method for assessing the risks of low quality products has been developed

KEYWORDS

qualimetry; risk assessment; risk of low quality; summarizing indicator; multicriteria quality assessment; dimensionless scale

\section{INTRODUCTION}

One of the principles of development and implementation of the international standard [ISO 9001:2015] is the principle of risk assessment, which requires companies and organizations to develop methods for analyzing, forecasting and risk management. The requirements of this standard indicate that the organization should: "identify and assess risks and opportunities that may affect the quality management system and the results of the work of organization; create a plan to respond to risks and opportunities; make decisions based on the results of risk assessment."

At the manufacturing enterprise, the sources of risk are associated not only with the main production activity, but also with all stages of the product life cycle, related activities, actions of employees, stakeholders, and others. To successfully manage risks you need to be able to analyze and forecast them, which will increase the efficiency of management processes. The purpose of the risk assessment process is to determine the magnitude and probability of adverse effects.

Today there are no universal methods of risk assessment for different enterprises or processes, so the enterprise must independently determine the method of analysis, in terms of its feasibility, depending on: the complexity and nature of the system under study; methods of control; properties that provide traceability, repeatability and controllability. The way out of this situation is to develop a standard methodology for risk assessment for groups of processes, among which are important processes of the production cycle [Panda 2014, 2018a,b, 2019; Valicek 2016 \& 2017, Macala 2009 \& 2017, Pandova 2018, Monkova 2013, Dyadyura 2017, Pollak 2020a,b, Olejarova 2017, Rimar 2016, Straka 2018a,b].

The aim of the paper is to develop a methodology for assessing the production risks of manufacturing low quality products. This method must be universal so that it can be used in different enterprises for the manufacture of various products [Mrkvica 2012, Cacko 2014].

\section{MATERIALS AND METHODS}

Traditionally, risk assessments are performed in various ways, based, for example, on a combination of observations, trends and other information. We can identify the most common methods of risk assessment:

- Basic auxiliary methods of risk management (flowcharts, control charts, etc.);

- Failure Mode Effects Analysis (FMEA);

- Failure Mode, Effects and Criticality Analysis (FMECA);

- Fault Tree Analysis (FTA);

- Hazard Analysis and Critical Control Points (HACCP);

- Hazard Operability Analysis (HAZOP).

- Preliminary Hazard Analysis (PHA);

- Risk ranking and filtering;

- Appropriate statistical methods.

Currently, there are methods for calculating risks, which are conveniently divided into two groups:

qualitative methods allow to obtain averaged generalized information about the risk of harm to product groups or the value of risk for a particular type of product;

quantitative methods: statistical, which allow to obtain averaged over a homogeneous group of products or populations information about the risk (safety) of harm;

estimated (individual), allowing to obtain the value of risk for a particular type of product.

Conceptual aspects of risk management are highlighted in the experience of many scientists. As P. Tworek notes in her publication, in accordance with the new priorities caused by changes in society, there is a constant change of management structures, and thus traditional models of public administration become ineffective [Tworek 2016].

M. Sartor emphasizes in his research that in most developed countries of the world risk management is given considerable attention both in the private sector of the economy and in public administration at all levels. Scientists around the world are working to create effective risk management tools [Sartor 2020]. The results of research by scientists from Australia, New Zealand, Japan and a number of other countries are the development of international standards ISO 31000: 2009 "Risk Management. Principles and Guidelines" and ISO 73: 2009 Risk management. Dictionary". They have become effective tools used by private, state and municipal organizations in developed countries to develop, implement and continuously improve the risk management system as a mandatory component of management systems in general [Hogarth 2018]. 
The publication of N. Silva and M. Arrfelt studies the theoretical and practical issues of risk management in enterprises, including the functions and main stages of implementation of risk management [Silva 2021, Arrfelt 2018].

V. Zaloga analyzing the international standard of risk management ISO 31000: 2009, considers the relationship between the principles, system and process of risk management and changes in the terminology [Zaloga 2019]. A. Panda [Panda 2019] in his works underpins the basic principles and approaches on improving the risk management system in construction, namely the introduction of consulting engineers and advanced training of key personnel of construction companies.

Consider the various definitions of risk given by domestic and foreign authors:

1. Risk - a potential, numerically measurable possibility of loss. The concept of risk is characterized by uncertainty associated with the possibility of adverse situations and consequences during the project realization [Goel 2019].

2. Risk - the probability of losses, shortfalls of planned income, profit [Nepomnyashchyy 2017].

3. Risk is the uncertainty of our financial results in the future [Lagunova 2018].

4. G. Linton defines risk as the degree of uncertainty in obtaining future net income [Linton 2019].

6. Risk - the probability of loss of values (financial, material commodity resources) as a result of the activity, if the situation and conditions of the activity will change in a direction different from the risk provided by plans and calculations [Zaloga 2020]. 7. Risk - the impact of uncertainty on the goal [ISO 9001:2015]. The role of risk in the enterprise is very large, experts understand the importance of risk management, but in practice there are many controversial issues due to the lack of a holistic theory of risk management and the ambiguity of the use of different methods of their assessment.

An international standard has been developed for risk assessment [ISO 31000:2018]. This document provides recommendations for managing the risks faced by organizations in the process of ensuring the life cycle of products and services. The procedure for applying these recommendations can be adapted to any organization. This standard contains a general approach to risk management and is not highly specialized or industry-specific. It can be applied throughout the life cycle of the organization and to any activity, including decision-making at all levels.

To develop the standard [ISO 31000:2018], a standard [IEC 31010:2019] was developed, which provides recommendations for the selection and application of systematic methods of general risk assessment. Standard [IEC 31010:2019] is of a recommendatory nature, so it can serve as a guide for different types of management systems. Organizations that develop quality management systems in accordance with [ISO 9001:2015] should develop their documented procedures for risk assessment and management.

There are also qualimetric assesssment methods that can be used as a mathematical apparatus for risk assessment. In works [Trishch 2006a,b, 2020] to obtain estimates of different quality indicators on a dimensionless scale there was used the dependence, which had a double exponential form. The authors [Cherniak 2020, Trishch 2016, Ginevicius 2015] used the type of dependencies to keep the assessment of quality indicators on a dimensionless scale, using ordinal statistics.

Scientists, in their works [Ghoddousi 2017] to obtain estimates of quality indicators on a dimensionless scale use the method of
SAW (Simple Additive weighting), the meaning of which is in the application of weighting factors for individual quality indicators. The TOPSIS method is also often used - a method of multi-criteria evaluation, which uses a reference value of quality [Niu 2020, Gitinavard 2017]. The TOPSIS method is also used to obtain a comprehensive assessment of quality indicators [Bruno 2018, Krenicky 2020, Masdari 2021].

Methods are often used to evaluate processes in social research: PROMETHEE (Preference Ranking Organization Method for Enrichment Evaluation) [Thakkar 2021b]; MOORA (MultiObjective Optimization Method by Ratio Analysis) [Thakkar 2021a]; WASPAS (Weighted Aggregated Sum Product Assessmentset) of various social objects [Senapati 2021].

Thus, as a result of the analysis of scientific research, it can be concluded that qualimetry methods are used to assess the quality of qualimetry objects of different nature and in different fields and areas of research, so it is proposed to use them to develop methods for assessing the risk of low quality products.

\section{METHODS FOR ESTIMATING THE PROBABILITY OF LOW QUALITY PRODUCTS}

To achieve this goal, it is necessary to solve a number of scientific and applied problems:

Since the products are characterized not by one but by many quality indicators and they can have different scales and ranges of measurement, it is necessary to determine the function of the dependence of the measured quality indicators with their estimates on a dimensionless scale. That is, you need to determine the functionally dependent statistics.

Let's define the law of distribution of functionally dependent statistics as random variables. That is, it is necessary to know the density function of functionally dependent quantities on a dimensionless scale.

Knowing the law of distribution of random variables on a dimensionless scale, it is necessary to determine the probabilities of getting a random variable in a given evaluation interval.

To solve the problems, we will use the mathematical apparatus of qualimetry as a science of quantitative quality assessment. In qualimetry, when assessing the quality of objects, an important place is taken by the type of relationship between the measured quality indicators and their evaluation on a dimensionless scale, as quality indicators are not always evenly distributed and do not always have a linear mathematical relationship with their evaluation. To manage the quality of the object there are often used statistical methods of evaluation and management, where the basic information is not to know the law of distribution of quality in its units, but to know the law of distribution of their estimates on a dimensionless scale. Therefore, in the framework of this paper, we will investigate the patterns of distribution of quality indicators on a dimensionless scale.

The technological process is a complex system, the state of which is to be assessed, analyzed, forecast and, if necessary, adjusted to ensure product quality. Under the object of qualimetry, in this paper, we will consider the result of the technological process obtaining a product of a given quality.

As a result of the influence of random factors on the quality indicators of each product, we obtain results that change with each product. In quality management in such conditions, the methods of mathematical statistics are used mainly for statistical analysis. The purpose of statistical analysis is to study the properties of a random variable. The effectiveness of the application of mathematical statistics for quality assessment depends on the amount of statistical information. Statistical 
information is contained in the knowledge of the law of distribution of quality indicators, as a random variable and the presence of a significant number of sample values.

Let the random value of scattering of any quality indicator of the object of qualimetry $X$ be subject to the normal distribution law and be related to the random value $Y$ by the dependence $\mathrm{Y}=F(\mathrm{x})$ :

$$
F(x)=\left\{\begin{array}{cc}
0 & x_{i} \leq x_{i \min } \\
{\left[\frac{x_{i}-x_{i \min }}{x_{i \max }-x_{\text {min }}}\right]^{k}} & x_{i \min }<x_{i}>x_{i \max } \\
1 & x_{i} \geq x_{i \max }
\end{array}\right.
$$

where $x_{i}$ - the actual value of the quality indicator; $x_{i \text { min }}-$ the minimum allowable value of the quality indicator; $x_{i} \max -$ the maximum allowable value of the quality indicator; $k$ - the exponent (form parameter);

Let's find the probability density of a random variable $\mathrm{Y}$. As is known, the equation for finding the probability density function $q(y)$ of a random variable $Y$ has the form:

$$
q(y)=f(\psi(y))\left|\psi^{\prime}(y)\right|
$$

where $f(x)$ - the probability density of a random variable $\mathrm{X}$; $\psi(y)$ - is an inverse function to $y=F(x)$ and which, in the range of possible values of a random variable $X$, has a derivative. So, we find the function inverse to:

$$
y=\left[\frac{x_{i}-x_{i \min }}{x_{i \max }-x_{i \min }}\right]^{k}, x_{i \min }<x_{i}>x_{i \max } .
$$

As a result of algebraic transformations we have:

$$
x=\psi(y)=y^{\frac{1}{k}}\left(x_{\max }-x_{\min }\right)+x_{\min }, .
$$

Let's find the derivative of the function $x=x(y)$ :

$$
\begin{gathered}
x_{y}^{\prime}=(\psi(y))^{\prime}=\frac{1}{k} y^{\frac{1}{k}-1}\left(x_{\max }-x_{\min }\right), \\
x_{y}^{\prime}=\frac{\left(x_{\max }-x_{\min }\right)}{k}\left(\frac{1}{y^{1-\frac{1}{k}}}\right) .
\end{gathered}
$$

If the random scattering value of the quality index of any process $X$ is subject to the normal distribution law with the density function

$$
f(x)=\frac{1}{\sigma_{x} \sqrt{2 \pi}} e^{-\frac{\left(x-m_{x}\right)^{2}}{2 \sigma_{x}^{2}}},
$$

then the probability density function $q(y)$ of a random variable $y$ will look like this:

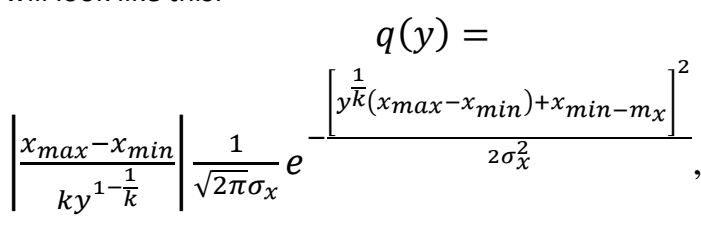

where $m x$ - mathematical expectation of the values of the quality indicator;

$\sigma x-$ is the standard deviation of the values of the quality indicator.
The methodology for assessing the risks of low quality products consists of the following steps:

To determine the quality of products (products);

To determine the permissible limits of their quality indicators. Permissible limits can be determined by relevant regulations.

To determine $x_{i \min }$ - the minimum allowable value of the quality indicator and and $x_{i \text { max }}$ - the maximum allowable value of the quality indicator;

To measure the true quality of the product $x_{i}$;

According to formula (1) to determine the value of the quality indicator $Y$ on a dimensionless scale;

Knowing the density function of the distribution law of a random variable $X$, we find the density function of a random variable $Y$ on a dimensionless scale. If the density function corresponds to the normal distribution law (2), then the probability density function $q(y)$ of the random variable $y$ will look like (3).

Knowing the density function of a random variable of a dimensionless quality indicator, we determine the probabilities of a random variable entering a given interval on a dimensionless scale by formula (4).

Therefore, knowing the law of distribution of individual indicators of product quality and knowing the dependence of their assessments on a dimensionless scale, it is possible to solve practical problems to determine the probability of assessments of quality indicators in a given assessment interval, i.e. to determine the risk of undesirable quality.

To test the method, it is proposed to use modeling of the process of scattering of product quality indicators as random variables, using the Monte Carlo method. 500 values of random variables were obtained according to the law of normal distribution with density function (2) and parameters: $m x=2,5 ; \sigma x=0,8$.

\section{RESULTS}

Applying the method of assessing the risks of low quality products, the following results were obtained (Fig. 1, Fig. 2, Fig. 3, Fig. 4). Here is (Fig. 1) a graph of the probability density function $q(y)$ of a random variable $y$, in the case when the parameters have the following values: $m x=2,5 ; \sigma x=0,8$, and the parameter of the form $\mathrm{k}$ changes.

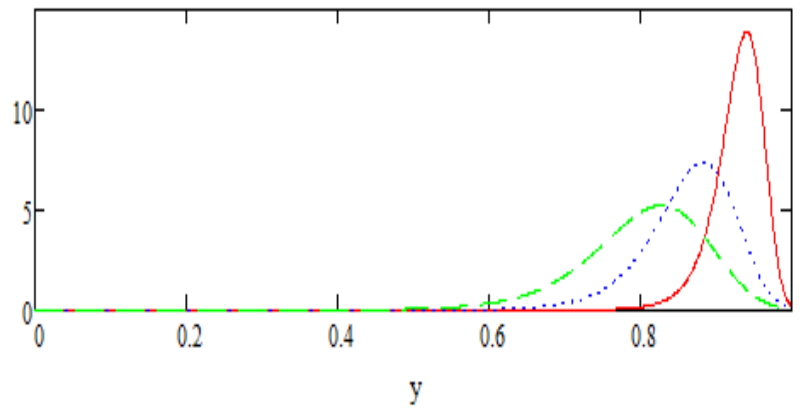

Figure 1. Graph of the probability density function of a random variable Y for shape parameters: $k=0,1 ; 0,2 ; 0,3$.

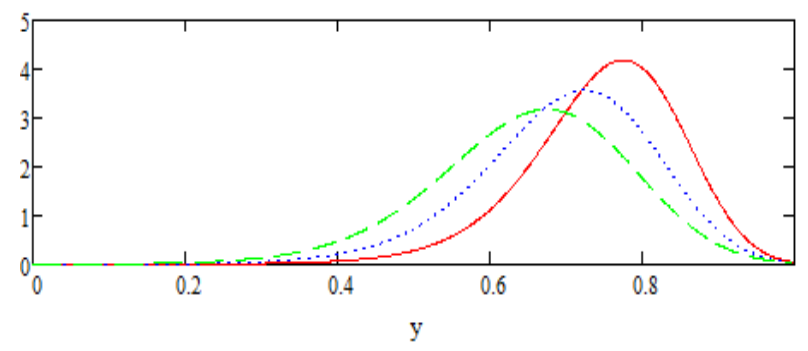


Figure 2. Graph of the probability density function of a random variable $\mathrm{Y}$ for shape parameters $\mathrm{k}=0,4 ; 0,5 ; 0,6$.

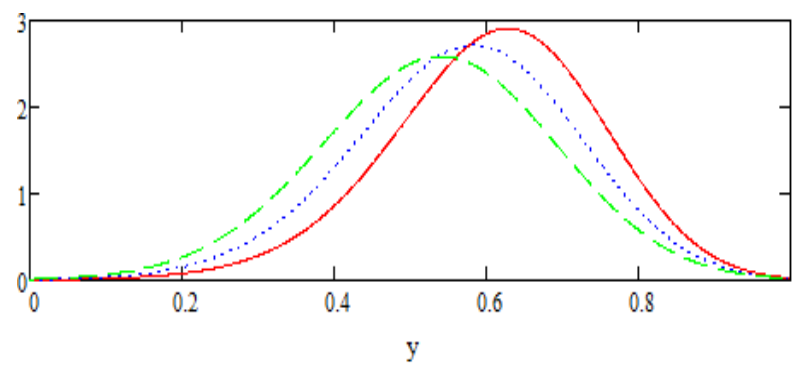

Figure 3. Graph of the probability density function of a random variable $Y$ for shape parameters: $k=0,7 ; 0,8 ; 0,9$.

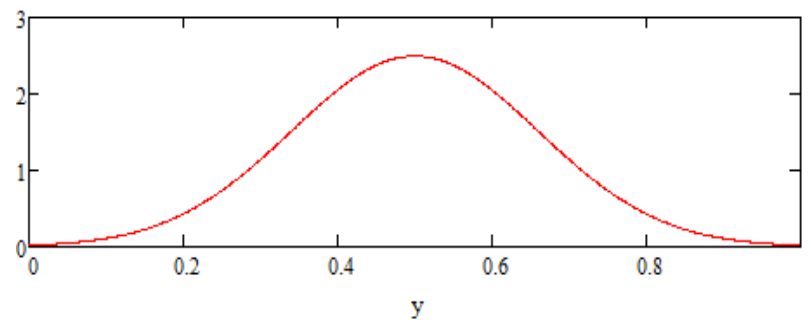

Figure 4. Graph of the probability density function of a random variable $\mathrm{Y}$ at a shape parameter: $\mathrm{k}=1$.

If the probability density function for a random variable $Y$ is known, then a number of practical problems can be solved, in particular, to find the probability that the value of a random variable $Y$ falls within a certain range $(c ; d)$ :

$$
P(c<y<d)=\int_{c}^{d} q(y) d y=F(d)-F(c),
$$

where $q(y)$ - distribution function of a random variable $\mathrm{Y}$.

Let's consider some practical task - It's find the probability that the values of a random variable $Y$ fall into the interval $(c ; d)$. To do this, it is necessary to calculate the integral:

$$
P(c<y<d)=\int_{c}^{d} q(y) d y .
$$

As a result of the calculations we obtained the results presented in Table 1.

Table 1. The probability of hitting the value of a random variable $Y$ in the

\begin{tabular}{|c|c|c|c|c|c|c|c|c|c|c|c|}
\hline \multicolumn{12}{|c|}{ Interval c-d } \\
\hline $\mathrm{k}$ & $0-0,1$ & $\begin{array}{l}0,1- \\
0,2\end{array}$ & $0,2-0,3$ & $0,3-0,4$ & $\begin{array}{l}0,4- \\
0,5\end{array}$ & $\begin{array}{l}0,5- \\
0,6\end{array}$ & $\begin{array}{l}0,6- \\
0,7\end{array}$ & $\begin{array}{l}0,7- \\
0,8\end{array}$ & $\begin{array}{l}0,8- \\
0,9\end{array}$ & $0,9-1$ & $\begin{array}{l}0 \\
- \\
1\end{array}$ \\
\hline \multicolumn{12}{|c|}{ Probability $P(c<y<d)$} \\
\hline $\begin{array}{l}0, \\
1\end{array}$ & $\begin{array}{l}1,9 \times 10 \\
-12\end{array}$ & $\begin{array}{l}1,9 \times 1 \\
0-9\end{array}$ & $\begin{array}{l}1,09 \times 1 \\
0-7\end{array}$ & $2 \times 10-6$ & $\begin{array}{l}1,7 \times 1 \\
0-5\end{array}$ & $\begin{array}{l}1 \times 10- \\
4\end{array}$ & $\begin{array}{l}6 \times 1 \\
0-4\end{array}$ & $\begin{array}{l}5,5 \times 1 \\
0--3\end{array}$ & $\begin{array}{l}0,16 \\
5\end{array}$ & 0,827 & 1 \\
\hline $\begin{array}{l}0, \\
2\end{array}$ & $\begin{array}{l}1,9 \times 10 \\
-7\end{array}$ & $\begin{array}{l}5,9 \times 1 \\
0-6\end{array}$ & $4 \times 10-5$ & $\begin{array}{l}1,7 \times 10 \\
-4\end{array}$ & \begin{tabular}{|l|}
$5,9 \times 1$ \\
$0-4$
\end{tabular} & $\begin{array}{l}2,5 \times 1 \\
0-3\end{array}$ & $\begin{array}{l}0,01 \\
5\end{array}$ & 0,122 & $\begin{array}{l}0,57 \\
3\end{array}$ & 0,285 & 1 \\
\hline $\begin{array}{l}0 \\
3 \\
\end{array}$ & $\begin{array}{l}8,8 \times 10 \\
-6\end{array}$ & \begin{tabular}{|l}
$8,4 \times 1$ \\
$0-5$
\end{tabular} & $\begin{array}{l}3,2 \times 10 \\
-4\end{array}$ & $\begin{array}{l}1,03 \times 1 \\
0-3\end{array}$ & \begin{tabular}{|l|}
$3,8 \times 1$ \\
$0-3$
\end{tabular} & 0,017 & $\begin{array}{l}0,08 \\
7\end{array}$ & 0,328 & 0,46 & 0,1 & 1 \\
\hline $\begin{array}{l}0 \\
4 \\
\end{array}$ & \begin{tabular}{|l}
$6,2 \times 10$ \\
-5 \\
\end{tabular} & $\begin{array}{l}, 4 \times 1 \\
0-4\end{array}$ & $\begin{array}{l}1,1 \times 10 \\
-3\end{array}$ & $4 \times 10-3$ & 0,015 & 0,062 & $\begin{array}{l}0,20 \\
3\end{array}$ & 0,388 & $\begin{array}{l}0,27 \\
9\end{array}$ & 0,046 & 1 \\
\hline $\begin{array}{l}0, \\
5 \\
\end{array}$ & $\begin{array}{l}2,09 \times 1 \\
0-4 \\
\end{array}$ & $\begin{array}{l}9,2 \times 1 \\
0-4\end{array}$ & $\begin{array}{l}3,2 \times 10 \\
-3\end{array}$ & 0,012 & 0,042 & 0,132 & $\begin{array}{l}0,28 \\
4 \\
\end{array}$ & 0,334 & $\begin{array}{l}0,16 \\
4\end{array}$ & 0,025 & 1 \\
\hline $\begin{array}{l}0, \\
6\end{array}$ & \begin{tabular}{|l}
$5,04 \times 1$ \\
$0-4$
\end{tabular} & $\begin{array}{l}2,1 \times 1 \\
0-3\end{array}$ & $\begin{array}{l}7,7 \times 10 \\
-3\end{array}$ & 0,027 & 0,085 & 0,2 & $\begin{array}{l}0,30 \\
3\end{array}$ & 0,255 & $\begin{array}{l}0,10 \\
1\end{array}$ & 0,016 & 1 \\
\hline $\begin{array}{l}0 \\
7 \\
\end{array}$ & $\begin{array}{l}1,03 \times 1 \\
0-3\end{array}$ & $\begin{array}{l}4,3 \times 1 \\
0-3\end{array}$ & 0,016 & 0,053 & 0,136 & 0,244 & 0,28 & 0,186 & $\begin{array}{l}0,06 \\
6\end{array}$ & 0,011 & 1 \\
\hline $\begin{array}{l}0 \\
8\end{array}$ & $\begin{array}{l}1,9 \times 10 \\
-3\end{array}$ & $\begin{array}{l}8,3 \times 1 \\
0-3\end{array}$ & 0,03 & 0,087 & 0,182 & 0,26 & 0,24 & 0,136 & $\begin{array}{l}0,04 \\
5\end{array}$ & $\begin{array}{l}8,4 \times 1 \\
0-3\end{array}$ & 1 \\
\hline
\end{tabular}
interval (c; d), provided that k varies from 0.1 to 1 at 0.1 intervals.

\begin{tabular}{|l|l|l|l|l|l|l|l|l|l|l|l|}
\hline $\begin{array}{l}0, \\
9\end{array}$ & $\begin{array}{l}3,2 \times 10 \\
-3\end{array}$ & 0,015 & 0,05 & 0,124 & 0,215 & 0,254 & $\begin{array}{l}0,19 \\
8\end{array}$ & 0,1 & $\begin{array}{l}0,03 \\
2\end{array}$ & $\begin{array}{l}6,6 \times 1 \\
0-3\end{array}$ & 1 \\
\hline 1 & $\begin{array}{l}5,3 \times 10 \\
-3\end{array}$ & 0,024 & 0,075 & 0,16 & 0,234 & 0,234 & 0,16 & 0,075 & $\begin{array}{l}0,02 \\
4\end{array}$ & $\begin{array}{l}5,3 \times 1 \\
0-3\end{array}$ & 1 \\
\hline
\end{tabular}

The table shows that, knowing the parameter of the form $k$, we have the probability of getting a dimensionless value of the evaluation of the quality indicator in any interval on the dimensionless scale. For example, using table (1) we find the probability that the estimate of product quality will be less than 0.8 at $\mathrm{k}=0.3$. Therefore, $\mathrm{P}(0<\mathrm{y}<0.8)=0.44$. Thus, you can find the probability of getting the value of the dimensionless evaluation of the quality indicator in any interval on the dimensionless scale.

\section{CONCLUSIONS}

The result of this paper is a method for determining the probability of low quality products. To develop a methodology:

1. Substantiated the function of dependence of the measured quality indicators with their estimates on a dimensionless scale, which allowed obtaining functionally dependent statistics.

2. Determined the density functions (Fig. $1-4$ ) of functionally dependent random variables of quality indicators, provided that the quality indicators are subject to the normal distribution law. 3. Performed testing of the method and determined the probabilities of random variables in a given evaluation interval (Table 1).

\section{ACKNOWLEDGMENTS}

This work was supported by the project 0119 U100361 of the Ministry of Education and Science of the Ukraine. The authors would like to thank the Ministry of Education and Science of the Ukraine grant agency for supporting research work and co-financing the project MES: $0119 U 100361$.

\section{REFERENCES}

[Arrfelt 2018] Arrfelt, M., Mannor, M., Nahrgang, J.D. et al. All risk-taking is not the same: examining the competing effects of firm risk-taking with meta-analysis. Rev Manag Sci 2018, Vol. 12, pp. 621-660.

[Bruno 2018] Bruno, G., Genovese, A. Multi-Criteria DecisionMaking: advances in theory and applications - an introduction to the special issue. Soft Comput, 2018, Vol. 22, pp. 7313-7314.

[Cacko 2014] Cacko, P., Krenicky, T. Impact of lubrication interval to operating status of bearing. Applied Mechanics and Materials, 2014, Vol. 616, pp. 151-158. ISSN 1660-9336.

[Cherniak 2020] Cherniak, O., Trishch, R., Kim, N., Ratajczak, S. Quantitative assessment of working conditions in the workplace. Engineering Management in Production and Services, 2020, Vol. 2, No. 12, pp. 99-106.

[Ghoddousi 2017] Ghoddousi, P., Ansari, R. \& Makui, A. A riskoriented buffer allocation model based on critical chain project management. KSCE J Civ Eng 2017, Vol. 21, pp. 1536-1548.

[Ginevicius 2015] Ginevicius, R., Trishch, H., Petraskevicius, V. Quantitative assessment of quality management systems' processes. Economic Research-Ekonomska Istraživanja, 2015, Vol. 1, No. 28, pp. 1096-1110.

[Gitinavard 2017] Gitinavard, H., Mousavi, S.M. \& Vahdani, B. Soft computing-based new interval-valued hesitant fuzzy multicriteria group assessment method with last aggregation to 
industrial decision problems. Soft Comput, 2017, Vol. 21, pp. 3247-3265.

[Goel 2019] Goel, R.K., Göktepe-Hultén, D. Risk attitudes, patenting and invention disclosures by academic researchers. J Technol Transf, 2019, Vol. 44, pp. 155-166.

[Hogarth 2018] Hogarth, K., Hutchinson, M. \& Scaife, W. Corporate Philanthropy, Reputation Risk Management and Shareholder Value: A Study of Australian Corporate giving. J Bus Ethics, 2018, Vol. 151, pp. 375-390.

[IEC 31010:2019] IEC 31010:2019 Risk management - Risk assessment techniques Risk management - Risk assessment techniques. International Organization for Standardization, 2019. Available at: https://www.iso.org/standard/51073.html [downloaded Apr. 1, 2021].

[ISO 9001:2015] ISO 9001:2015 Quality management systems Requirements. International Organization for Standardization, 2015. Available at: https://www.iso.org/standard/62085.html [downloaded Apr. 1, 2021].

[ISO 31000:2018] ISO 31000:2018 Risk management Guidelines. International Organization for Standardization, 2018. Available at: www.iso.org/standard/65694.html [downloaded Apr. 1, 2021].

[Karrach 2020] Karrach, L., Pivarciova, E., Bozek, P. Recognition of perspective distorted $Q R$ codes with a partially damaged finder pattern in real scene images. Applied Sciences, 2020, Vol. 10, issue 21, Art. No. 7814. ISSN 2076-3417.

[Krenicky 2020] Krenicky, T., Servatka, M., Gaspar, S., Mascenik, J. Abrasive Water Jet Cutting of Hardox Steels-Quality Investigation. Processes, 2020, Vol. 8, Issue 12, Art. No. 1652.

[Lagunova 2018] Lagunova, I.A. The essence and principles of the concept of risk management. Pressing problems of public administration, 2018, Vol. 1, No. 53, pp. 44-51.

[Linton 2019] Linton, G. Innovativeness, risk-taking, and proactiveness in startups: a case study and conceptual development. J Glob Entrepr Res 2019, Vol. 9, Art. No. 20.

[Macala 2009] Macala, J., Pandova, I., Panda, A. Clinoptilolite as a mineral usable for cleaning of exhaust gases. Mineral resources management, 2009, Vol. 25, No. 4, pp. 23-32. ISSN 0860-0953.

[Macala 2017] Macala, J., Pandova, I., Panda, A. Zeolite as a prospective material for the purification of automobile exhaust gases. Mineral resources management, 2017, Vol. 33, No. 1, pp. 125-138. ISSN 0860-0953.

[Masdari 2021] Masdari, M., Khezri, H. Service selection using fuzzy multi-criteria decision making: a comprehensive review. J Ambient Intell Human Comput, 2021, Vol. 12, pp. 2803-2834.

[Monkova 2013] Monkova, K., Monka, P., Jakubeczyova, D. The research of the high speed steels produced by powder and casting metallurgy from the view of tool cutting life. Applied Mechanics and Materials, 2013, Vol. 302, pp. 269-274.

[Mrkvica 2012] Mrkvica, I., Janos, M., Sysel, P. Cutting efficiency by drilling with tools from different materials. Advanced Materials Research, 2012, Vols. 538-541, pp. 1327-1331.

[Nepomnyashchyy 2017] Nepomnyashchyy, O. M. Engineering: some aspects of key personnel training." Pressing problems of public administration, 2017, Vol. 2, pp. 144-151.

[Niu 2020] Niu, L., et al. Multi-criteria decision-making method with double risk parameters in interval-valued intuitionistic fuzzy environments. Complex Intell. Syst., 2020, Vol. 6, pp. 669-679.
[Olejarova 2017] Olejarova, S., Dobransky, J., Svetlik, J., Pituk, M. Measurements and evaluation of measurements of vibrations in steel milling process. Measurement: Journal of the International Measurement Confederation, 2017, Vol. 106, pp. 18-25.

[Panda 2014] Panda, A., Duplak, J. Comparison of theory and practice in analytical expression of cutting tools durability for potential use at manufacturing of bearings. Applied Mechanics and Materials, 2014, Vol. 616, pp. 300-307. ISSN 1662-7482.

[Panda 2018a] Panda, A., Dobransky, J., Jancik, M., Pandova, I., Kacalova, M. Advantages and effectiveness of the powder metallurgy in manufacturing technologies. Metalurgija, 2018, Vol. 4, No. 57, pp. 353-356.

[Panda 2018b] Panda, A., Olejarova, S., Valicek, J., Harnicarova, M. Monitoring of the condition of turning machine bearing housing through vibrations. International Journal of Advanced Manufacturing Technology, 2018, Vol. 97, No. 1-4, pp. 401-411.

[Panda 2019] Panda, A., et al. Development of the method for predicting the resource of mechanical systems. Int J of Advanced Manufacturing Technology, 2019, Vol. 105, pp. 1563-1571.

[Pandova 2018] Pandova, I., et al. Use of sorption of copper cations by clinoptilolite for wastewater treatment. International Journal of Environmental Research and Public Health, 2018, Vol. 15, No. 7, pp. 1-12. ISSN 1661-7827.

[Pollak 2020a] Polllak, M., Dobransky, J. Structural design and material cutting using a laser end effector on a robot arm. TEM Journal, 2020, Vol. 9, No. 4, pp. 1455-1459, ISSN 2217-8309.

[Pollak 2020b] Polllak, M., Kocisko, M., Paulisin, D., Baron, P. Measurement of unidirectional pose accuracy and repeatability of the collaborative robot UR5. Advances in Mechanicl Engineering, 2020, Vol. 12, No. 12, pp. 1-21.

[Rimar 2016] Rimar, M., Smeringai, P., Fedak M., Kuna S. Technical and software equipment for the real time positioning control system in mechatronic systems with pneumatic artificial muscles. Key Engineering Materials, 2016, Vol. 669, pp. 361-369. [Sartor 2020] Sartor, M.A., Beamish, P.W. Private Sector Corruption, Public Sector Corruption and the Organizational Structure of Foreign Subsidiaries. J Bus Ethics, 2020, Vol. 167, pp. 725-744.

[Senapati 2021] Senapati, T., Yager, R.R. \& Chen, G. Cubic intuitionistic WASPAS technique and its application in multicriteria decision-making. J Ambient Intell Human Comput, 2021.

[Silva 2021] Silva, N., Sousa, P. \& Mira da Silva, M. Maintenance of Enterprise Architecture Models. Bus Inf Syst Eng 2021, Vol. 63, pp. 157-180.

[Straka 2018a] Straka, L., Hasova, S. Optimization of material removal rate and tool wear rate of $\mathrm{Cu}$ electrode in die-sinking EDM of tool steel. Int J of Advanced Manufacturing Technology, 2018, Vol. 97, No. 5-8, pp. 2647-2654.

[Straka 2018b] Straka, L., Hasova, S. Prediction of the heataffected zone of tool steel EN X37CrMoV5-1 after die-sinking electrical discharge machining. In: Proc. of the institution of mechanical engineers part B - Journal of engineering manufacture, 2018, Vol. 232, No. 8, pp. 1395-1406.

[Tang 2020] Tang, M., Wang, TD. \& Peng, DH. An improved Taguchi multi-criteria decision-making method based on the hesitant fuzzy correlation coefficient and its application in quality evaluation. J Ambient Intell Human Comput, 2020.

[Thakkar 2021a] Thakkar J.J. Multi-objective Optimization on the Basis of Ratio Analysis Method (MOORA). Multi-Criteria Decision Making. Studies in Systems, Decision and Control, 2021, Vol. 336. 
[Thakkar 2021b] Thakkar J.J. Preference Ranking Organization Method for Enrichment Evaluations (PROMETHEE). Multi-Criteria Decision Making. Studies in Systems, Decision and Control, 2021, Vol. 336.

[Trishch 2006a] Trishch, R.M., Slityuk, E.A. Generalized point and interval evaluation items ICE workmanship. Eastern-European J. of Enterprise Technologies, 2006, Vol. 1, No. 19, pp. 63-67.

[Trishch 2006b] Trishch, R.M., Slityuk, E.A. Spot and interval evaluation of product quality. Bulletin of the NTU "KhPI". Collection of scientific works, 2006, Vol. 27, pp. 96-102.

[Trishch 2016] Trishch, R., Gorbenko, E., Dotsenko, N., Kim, N., Kiporenko, A. Development of qualimetric approaches to the processes of quality management system at enterprises according to international standards of the ISO 9000 series. EasternEuropean J. of Enterprise Technologies, 2016, Vol. 4, No. 82, pp. 18-24.

[Trishch 2020] Trishch, R., Maletska, O., Cherniak, O., Semionova, Ju., Jancis, V. Analysis of the requirements of international and national standards for measure-ment methods and metrological equipment. Innovative Technologies and Scientific Solutions for Industries, 2020, Vol. 1, No. 11, pp. 156-162.

[Tworek 2016] Tworek P. Risk Management in Public Sector Organizations. In: 8th Int. Sci. Conf. Managing and Modelling of Financial Risks. Ostrava, VSB-TU of Ostrava, Faculty of Economics, Department of Finance, 2016, pp. 1022-1029.
[Valicek 2016] Valicek, J., et al. A new approach for the determination of technological parameters for hydroabrasive cutting of materials. Materialwissenschaft und Werkstofftechnik, 2016, Vol. 47, No. 5-6, pp. 462-471. ISSN 0933-5137.

[Valicek 2017] Valicek, J., et al. Identification of Upper and Lower Level Yield strength in Materials. Materials, 2017, Vol. 10, No. 9, pp. 1-20. ISSN 1996-1944.

[Zaloga 2019] Zaloga, V., Dyadyura, K., Rybalka, I., Pandova, I. Implementation of Integrated Management System in Order to Enhance Equipment Efficiency. Management Systems in Production Engineering, 2019, Vol. 4, pp. 221-226.

[Zaloga 2020] Zaloga, V., Dyadyura, K., Rybalka, I., Pandova, I., Zaborowski, T. Enhancing efficiency by implementation of integrated management system in order to align organisational culture and daily practice. Management Systems in Production Engineering, 2020, Vol. 28, No. 4, pp. 304-311.

\section{Contact:}

Prof. Ing. Konstantin Dyadyura, PhD.

Sumy State University

Faculty of Technical Systems and Energy Efficient Technologies

Rymskogo-Korsakova st. 2, 40007 Sumy, Ukraine

dyadyura@pmtkm.sumdu.edu.ua 